\title{
Specific adaptation of gastric emptying to diets with differing protein content in the rat: is endogenous cholecystokinin implicated?
}

G Shi, V Leray, C Scarpignato, N Bentouimou, S Bruley des Varannes, C Cherbut, J-P Galmiche

\begin{abstract}
Background-Recent studies indicate that gastric emptying may be influenced by patterns of previous nutrient intake. Endogenous cholecystokinin (CCK), whose synthesis and release can be affected by dietary intake, has a major role in the regulation of gastric emptying.

Aims-To evaluate the influence of diets with differing protein content on gastric emptying of differing liquid test meals and plasma CCK levels in the rat and to check whether the inhibitory effect of exogenous CCK on gastric emptying is modified after long term intake of diets with differing protein content.
\end{abstract}

Methods-Rats were fed for three weeks with high protein, medium protein (regular), or low protein diet. On day 22 gastric emptying of a peptone meal was studied. In addition, basal and postprandial CCK levels after the different dietary regimens were measured by bioassay. The time course of dietary adaptation was studied and its specificity assessed through the use of different (peptone, glucose, and methylcellulose) test meals. The effect of exogenous CCK-8 on gastric emptying was studied at the end of the adaptation period (three weeks).

Results-Feeding the animals with a high protein diet for three weeks resulted in a significant $(p<0.05)$ acceleration (by 21.2 $(8.2) \%)$ of gastric emptying while feeding with a low protein diet was followed by a significant $(p<0.05)$ delay (by $24.0(6.2) \%)$ in the emptying rate. When the time course of the effect of dietary adaptation on gastric emptying was studied, it appeared that at least two weeks are required for dietary protein to be effective. The regulatory effect of dietary protein on gastric emptying proved to be dependent on meal composition. Only the emptying rate of a protein containing meal $(40 \%$ peptone) was significantly modified by previous dietary intake. No significant ( $p>0.05$ ) changes were observed with glucose and methylcellulose meals whose emptying rates were similar in rats receiving a high protein or low protein diet. A peptone meal strongly and significantly $(p<0.05)$ increased plasma CCK levels in rats fed a medium protein (regular) diet. Results were similar in rats receiving a low protein diet $(\mathrm{p}<0.05)$ but not in rats on a high protein diet $(p>0.05)$. As a consequence, postprandial plasma levels of CCK in rats fed with a medium or low protein diet were significantly $(p<0.05)$ higher than those in rats receiving a high protein diet. In rats on high and low protein diets, dose response curves to CCK-8 were virtually identical, suggesting that dietary protein intake has no influence on the effect of exogenous CCK.

Conclusions-These results clearly show that gastric emptying of a protein containing meal can be modified by previous dietary protein intake. This effect, which is time dependent and meal specific, may be related to changes in endogenous CCK release which will affect emptying rate. While the exact mechanisms underlying this adaptive response need to be studied and clarified further, these results emphasise the importance of dietary history in the evaluation and interpretation of gastric emptying data.

(Gut 1997; 41: 612-618)

Keywords: diet; protein content; gastric emptying; cholecystokinin

Dietary factors, including the volume, osmolarity, viscosity, $\mathrm{pH}$, and content of the meal are important in the physiological control of gastric emptying. ${ }^{1}$ Recent studies indicate that gastric emptying may actually be influenced by patterns of previous nutrient intake. In humans, both gastric emptying and mouth to caecum transit are faster after a period on a high fat diet than after the same period on a low fat diet. ${ }^{2}$ Supplementation of the diet with glucose for several days accelerates the emptying of a hyperosmotic drink of glucose ${ }^{3}$ or the emptying of glucose and fructose ${ }^{4}$ from the human stomach. Conversely, gastric emptying of glucose is delayed by a four day fast in humans. ${ }^{5}$ Results obtained from animal experiments, performed in rats, have also shown that dietary restriction results in a significant delay in gastric emptying, which returns to normal after a period of free feeding. ${ }^{6}$ In both studies, however, restriction of energy intake was excessive enough to result in malnutrition. The effect of changes in meal content (without any restriction of energy intake) on gastric emptying has not yet been studied in the rat. 
TABLE 1 Composition of the diets

\begin{tabular}{lccc}
\hline Ingredient & $\begin{array}{l}\text { Low protein diet } \\
(\mathrm{g} / 100 \mathrm{~g} \text { diet })\end{array}$ & $\begin{array}{l}\text { Medium protein diet } \\
(\mathrm{g} / 100 \mathrm{~g} \text { diet })\end{array}$ & $\begin{array}{l}\text { High protein diet } \\
(\mathrm{g} / \text { 100 g diet })\end{array}$ \\
\hline Proteins & 9.2 & 17.0 & 55.9 \\
$\quad$ Casein & 3.3 & & 50.0 \\
$\quad$ Other proteins & 5.9 & 17.0 & 5.9 \\
Carbohydrates & 75.4 & 58.7 & 28.7 \\
$\quad$ Dextrin & 55.8 & 58.7 & 9.1 \\
$\quad$ Other carbohydrates & 19.6 & 3.0 & 19.6 \\
Lipids & 4.3 & 4.0 & 4.3 \\
Fibre & 1.4 & 12.0 & 1.4 \\
Water & 4.0 & 5.0 & 4.0 \\
Minerals & 5.0 & 0.3 & 5.0 \\
Vitamin mixture & 0.7 & 1.38 & 0.7 \\
Energy content $(M J 100 \mathrm{~g})$ & 1.58 & 1.58
\end{tabular}

${ }^{\star}$ Other proteins include animal (fish) protein and vegetable (soya bean meal, yeast) protein at a ratio of 2:7. † Other carbohydrates are from cereals and cereal byproducts (including $13 \% \mathrm{starch}$ ). High and low protein diets were prepared by adding casein and dextrin to the medium protein diet so that they contained $3.3 \%$ and $50 \%$ casein, respectively. Appropriate quantities of lipids, minerals and the vitamin mixture were added. The medium protein diet was rat and mouse maintenance diet A-04 from UAR, France.

There is growing evidence in the literature suggesting the involvement of endogenous cholecystokinin (CCK) in the regulation of gastric motor function. ${ }^{8-15}$ On the other hand, CCK synthesis and release can be affected by dietary intake in both physiological and pathological conditions. In elderly patients with protein energy undernutrition, postprandial plasma CCK levels were found to be significantly higher than those found in healthy (both young and aged) subjects, suggesting that the peptide hypersecretion is related to malnutrition instead of to aging. ${ }^{16}$ On the contrary, in obese patients, the plasma CCK response to sham feeding was significantly lower when compared with that found in normal weight (age and sex matched) subjects. ${ }^{17}$ When compared with healthy controls, in patients with anorexia nervosa, an earlier and greater rise in plasma CCK levels after a liquid meal was observed, a pattern which was normalised with nutrition therapy. ${ }^{18}$ Animal experiments have shown that-during adaptation to increased dietary proteins - there is a notable, although transient, increase in plasma CCK levels. ${ }^{19}$ On the contrary, after food deprivation, plasma CCK levels decrease rapidly and this decrease is followed by a reduction in duodenal CCK mRNA and mucosal CCK peptide levels. Only one day of refeeding was sufficient to restore to control levels all the above parameters. ${ }^{20}$ No study has, however, investigated the effects of changes in endogenous CCK levels, induced by chronic intake of different concentrations of protein, on gastric emptying.

The aim of present study was therefore twofold: to evaluate the influence of diets with differing protein content on gastric emptying of different liquid test meals, plasma CCK levels, and CCK mRNA in duodenal mucosa of rats; and to check whether the inhibitory effect of exogenous CCK on gastric emptying is modified after long term intake of diets with differing protein content.

\section{Materials and Methods}

ANIMALS AND DIETS

Male Wistar rats (aged 6-7 weeks, weighing 180-210 g at the start of the experiment) were used in this study. They were maintained on a
12 hour light dark cycle, with lights on at 0800 and off at 2000, and were fed with three different diets (table 1) during different periods. During the course of the experiments, food consumption and body weights were recorded daily.

MEASUREMENT OF GASTRIC EMPTYING

Gastric emptying was measured by the method of Scarpignato et $a l^{122}$ with some modifications. Three different test meals were used: two nutrient (40\% peptone and $25 \%$ glucose) and one non-nutrient (1.5\% methylcellulose) meals. Both peptone and glucose were dissolved in distilled water to make their final concentration; phenol red $(1.0 \mathrm{mg} / \mathrm{ml})$ was then added as a non-absorbable marker. These two test meals were prepared a few days before experiments and stored at $4^{\circ} \mathrm{C}$. The nonnutrient test meal (the methylcellulose meal) was prepared as previously described. ${ }^{21}$ The $\mathrm{pH}$ values of $40 \%$ peptone, $25 \%$ glucose, and $1.5 \%$ methylcellulose were $6.9,7.0$, and 7.2 , respectively. The osmolarity was 1840 mosmol $/ \mathrm{kg}$ for $25 \%$ glucose and $8 \mathrm{mosmol} / \mathrm{kg}$ for $1.5 \%$ methylcellulose. The $40 \%$ peptone was actually a suspension of peptone in distilled water whose osmolarity cannot be measured.

All the prewarmed $\left(37^{\circ} \mathrm{C}\right)$ meals $(3 \mathrm{ml}$ for each rat) were given orally through a stainless steel tube after an 18 hour fast. Forty (for peptone test meal), 20 (for glucose test meal), or 15 (for methylcellulose meal) minutes later, rats were killed by cervical dislocation. The stomach was then ligated at the pylorus and cardia, opened along the greater curvature, and gastric contents collected in graduated tubes. The stomach was carefully rinsed three times with $30 \mathrm{ml}$ of distilled water and the rinsing solutions were added to gastric contents. The mixture was made up to $100 \mathrm{ml}$ with water and thoroughly mixed. Five millilitres of this mixture was centrifuged at $3100 \mathrm{rpm}$ at $4^{\circ} \mathrm{C}$ for 15 minutes. Supernatant $(1 \mathrm{ml})$ was then added to $5 \mathrm{ml} \mathrm{Na}{ }_{3} \mathrm{PO}_{4}(63.7 \mathrm{~g} / \mathrm{l})$ and vortexed. The phenol red concentration in each sample $\left(\mathrm{C}_{\text {sample }}\right)$ was determined spectrophotometrically at $523 \mathrm{~nm}$ and gastric emptying calculated according to the following formula:

Gastric emptying $\%=\frac{\mathrm{C}_{\text {standard }}-\mathrm{C}_{\text {sample }}}{\mathrm{C}_{\text {standard }}} \times 100 \%$

where $\mathrm{C}_{\text {standard }}$ represents the phenol red concentration found in the stomach of rats sacrificed immediately after administration of the test meal.

\section{EXPERIMENTAL DESIGN}

Effect of type of protein intake on gastric emptying In order to check whether diets with differing protein content could affect emptying rate of a protein containing (peptone) meal, three sets of experiments were performed.

In the first set, three groups of rats (six to eight animals) were fed for 21 days with a high protein, medium protein (regular), or low protein diet (see table 1). On day 22, gastric emptying of the peptone test meal was measured. In 
order to check whether the modification of gastric emptying is reversible, two groups of rats were fed for 21 days with a high protein or low protein diet, respectively, and then changed to a medium protein (regular) diet for seven days. Thereafter, gastric emptying of the $40 \%$ peptone meal was measured.

In a second set of experiments, the time course of dietary adaptation was studied. Eight groups of animals were fed with a high or low protein diet for $7,14,21$, or 30 days and gastric emptying of a peptone meal was quantified at the end of the adaptation period.

Finally, in order to check whether the dietary adaptation to protein affects "specifically" gastric emptying of a protein test meal, the influence of 21 days feeding with diets of differing protein content on gastric emptying of nutrient or non-nutrient meals was investigated. Six groups of rats were fed for three weeks with a high or low protein diet and gastric emptying of a peptone, glucose, or methylcellulose meal was measured.

\section{Effect of different types of protein intake on CCK release}

To evaluate the effect of dietary protein content on CCK release, six groups of rats (of six to nine animals each) were studied. They were fed with a low, medium (regular), or high protein diet for 21 days and on day 22 both basal plasma CCK levels (three groups) and plasma CCK levels eight minutes after intragastric administration of a protein meal (three groups) were measured by bioassay (see below). This time interval has been chosen since published results $^{23} 24$ and our own preliminary data has shown that after meals, the time to peak plasma CCK levels ranges from five to 10 minutes.

Effect of different types of protein intake on CCK $m R N A$

In two other groups of rats fed for three weeks with a high or low protein diet, duodenal mucosa was excised and CCK mRNA content measured by northern blot analysis (see below).

Effect of different types of protein intake on CCK-8 induced delay in gastric emptying

To evaluate whether diets with differing protein content could affect the gastric inhibitory activity of exogenous CCK-8, a dose response curve (percentage inhibition versus dose) of the peptide was constructed in animals fed for three weeks with a high or low protein diet. Eight groups of rats were given the diets with differing protein content and, at the end of the adaptation period, gastric emptying of a non-caloric liquid meal (methylcellulose) was measured after saline or three different doses of exogenous CCK-8, injected intraperitoneally five minutes before the meal.

CCK BIOASSAY

Plasma levels of CCK were measured by the specific and sensitive bioassay described by Liddle $e t$ al. $^{23}$ This method is based on the ability of CCK to stimulate amylase release from isolated rat pancreatic acini. Blood samples were centrifuged at $3500 \mathrm{rpm}$ for 10 minutes at $4^{\circ} \mathrm{C}$. The plasma was applied onto Sep-Pak C18 Cartridges (Waters Associates, Millipore Corp., Milford, Molsheim, France), previously activated with $10 \mathrm{ml}$ acetonitrile, $10 \mathrm{ml}$ ethanol, and $20 \mathrm{ml}$ water. After washing with $20 \mathrm{ml}$ water, CCK was eluted with $1 \mathrm{ml}$ acetonitrile: water (1:1). This eluate was then lyophilised for 72 hours and the corresponding extract stored at $-20^{\circ} \mathrm{C}$ until assayed

Acini were isolated by collagenase digestion of the pancreas. They were then suspended in a Tris buffer containing $40 \mathrm{mM}$ Tris, $115 \mathrm{mM}$ $\mathrm{NaCl}, 0.5 \mathrm{mM} \mathrm{CaCl}_{2}, 1.2 \mathrm{mM} \mathrm{MgSO}_{4}$, and $1.2 \mathrm{mM} \mathrm{KH} \mathrm{KHO}_{4}$ supplemented with $5 \mathrm{mM}$ glucose, $2 \mathrm{mM}$ glutamine, $2 \%$ of an essential amino acid solution, $1 \%$ of a non-essential amino acid solution, and $5 \mathrm{mg} / \mathrm{ml}$ bovine serum albumin, equilibrated with $\mathrm{O}_{2}: \mathrm{CO}_{2}$ (95:5), and adjusted to $\mathrm{pH} 7.4$ with $\mathrm{HCl}$.

Plasma CCK extracts were added to $1 \mathrm{ml}$ aliquots of acinar suspension and incubated for 30 minutes at $37^{\circ} \mathrm{C}$. Amylase release into the medium was measured using procion yellow starch as substrate. The total acinar amylase content was measured after lysis of cells by Triton X-100. Amylase release, expressed as a percentage of total amylase content, was quantified using a standard curve constructed with CCK-8.

CCK MRNA ASSAY

Duodenal CCK mRNA levels in response to a peptone test meal after a three week adaptation to either a high protein diet or a low protein diet were measured six hours after the test meal. This time interval was chosen after some preliminary work where we observed the highest mRNA levels six hours after the meal. This value was notably reduced after 24 hours and almost undetectable after 48 hours.

\section{$R N A$ isolation}

Immediately after sacrifice, the duodenum was removed and the luminal contents rinsed with iced phosphate buffered saline. The duodenum was then incised and the mucosa scraped off and immediately frozen in liquid nitrogen until RNA isolation. Total RNA was isolated from duodenal mucosal scrapings by the acid guanidinium thiocyanate-phenol-chloroform extraction method..$^{25}$ Duodenal scrapings were homogenised in $1 \mathrm{ml}$ of $4 \mathrm{M}$ guanidium thiocyanate, $25 \mathrm{mM}$ sodium citrate (per 100 $\mathrm{mg}$ of tissue), $0.1 \mathrm{M} \mathrm{2-mercaptoethanol} \mathrm{and}$ $0.5 \%$ sarcosyl. Then, in order, $0.1 \mathrm{ml}$ of $2 \mathrm{M}$ sodium acetate $\mathrm{pH} 4,1 \mathrm{ml}$ of phenol saturated in water, and $1 \mathrm{ml}$ of chloroform:isoamylic alcohol (49:1) were added. The homogenate was kept at $4^{\circ} \mathrm{C}$ for 15 minutes and centrifuged at $4^{\circ} \mathrm{C}$ for 20 minutes at $13000 \mathrm{rpm}$. The aqueous phase, containing RNA, was precipitated with $1 \mathrm{ml}$ of isopropanol for one hour at $-20^{\circ} \mathrm{C}$ and centrifuged at $4^{\circ} \mathrm{C}$ for 20 minutes at $13000 \mathrm{rpm}$. Pellets were dissolved with the guanidinium thiocyanate solution, then precipitated with isopropanol for at least one hour at $-20^{\circ} \mathrm{C}$. After centrifugation for 10 minutes at $13000 \mathrm{rpm}$, RNAs were washed with $75 \%$ ethanol, dried under vacuum, and dissolved in 
water. The concentration of RNA was determined spectrophotometrically. RNAs were concentrated to obtain $20 \mu \mathrm{g}$ per $7 \mu \mathrm{l}$.

\section{Northern blot analysis}

Total RNA $(20 \mu \mathrm{g})$ was denatured for $15 \mathrm{~min}$ utes at $60^{\circ} \mathrm{C}$ in $23 \mu \mathrm{l}$ of buffer $(20 \mathrm{mM}$ morphomolinopropane sulphonic acid, $5 \mathrm{mM}$ sodium acetate, and $1 \mathrm{mM}$ EDTA) containing $50 \%$ formamide (vol/vol) and $6 \%$ formaldehyde (vol/vol).

RNA samples were then electrophoresed in $1 \%$ agarose and $6 \%$ formaldehyde gel, and transferred to Hybond $\mathrm{N}$ nylon membranes (Amersham, Les Ulis, France). The nylon membranes were fixed in ultraviolet light for eight minutes, prehybridised for at least one hour at $42^{\circ} \mathrm{C}$ in hybridisation buffer containing $50 \%$ formamide (vol $/ \mathrm{vol}$ ), $0.08 \%$ bovine serum albumin (wt/vol), 0.08\% Ficoll (wt/vol), 0.08\% polyvinyl pyrolidone (wt/vol), $50 \mathrm{mM}$ phosphate buffer $\mathrm{pH} 6.5,900 \mathrm{mM} \mathrm{NaCl}, 1 \%$ sodium dodecyl sulphate (SDS) (wt/vol), 4\% dextran sulphate, $2 \mathrm{mM}$ EDTA, and $0.2 \mathrm{mg} / \mathrm{ml}$ of denatured herring sperm DNA.

The membranes were then hybridised for 16 hours at $42^{\circ} \mathrm{C}$ in the same solution with a cDNA probe of CCK (American Type Culture Collection), labelled by the random primer method with ${ }^{32} \mathrm{P}$-dCTP. Blots were then washed twice for 10 minutes in $500 \mathrm{ml}$ of $0.1 \%$ SDS, $0.5 \times$ SSC $(20 \times$ SSC: $3 \mathrm{M} \mathrm{NaCl}, 0.3 \mathrm{M}$ sodium citrate) at room temperature, and twice for 10 minutes in the same solution at $55^{\circ} \mathrm{C}$. Blots were subsequently stripped in a boiling solution of $0.1 \%$ SDS and then rehybridised with a ${ }^{32} \mathrm{P}$-labelled cDNA probe of phosphoglycerate kinase (PGK), a housekeeping gene. Signals were then quantified by a laser densitometer. Densitometric values obtained with CCK were expressed after normalisation with PGK values. As usual, results were expressed as the ratio of CCK mRNA to PGK mRNA to correct for any differences in total RNA recovery between samples and any small differences in the amount of RNA transferred to the Hybond $\mathrm{N}$ nylon membranes.

CHEMICALS

Synthetic sulphated CCK-8 (Bachem, Bubendorf, Switzerland) was dissolved in $0.9 \% \mathrm{NaCl}$ solution. Peptone (grade II), glucose, methylcellulose, phenol red, and routine chemicals were all purchased from Sigma (St Louis, Missouri, USA).

\section{STATISTICAL ANALYSIS}

As data are normally distributed, values are expressed as mean (SEM). Comparison among means was performed through analysis of variance followed by post hoc tests (Dunnett multiple comparisons test or Bonferroni test). A p value less than 0.05 was considered significant. All the calculations were made by using the Instat $^{\mathrm{TM}}$ software (GraphPad Software Inc., Berkeley, California, USA).

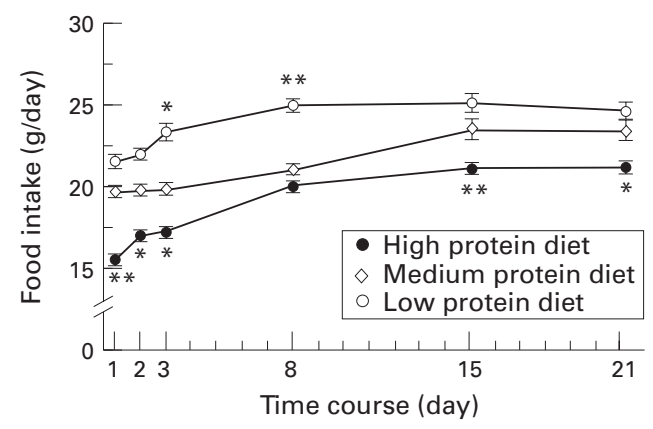

Figure 1: Food intake of rats fed with a high, medium, or low protein diet. Points represent the means. Vertical bars are standard errors. ${ }^{\star} p<0.05$ versus medium protein diet, ${ }^{\star \star} p<0.01$ versus medium protein diet.

\section{Results}

BODY WEIGHT AND FOOD CONSUMPTION DURING DIFFERENT DIETARY REGIMENS

Body weights of rats fed with diets with differing protein content were not dissimilar at any time interval during the adaptation periods (data not shown). Animals fed with a low protein diet ate more and animals on a high protein diet ate less than those receiving a medium protein (regular) diet (fig 1).

EFFECT OF DIFFERENT TYPES OF PROTEIN INTAKE ON GASTRIC EMPTYING

Under our experimental conditions, the peptone test meal leaving the stomach (gastric emptying) in control rats receiving a medium protein (regular) diet was 37.0 (1.6)\%. Feeding the animals with a high protein diet for three weeks resulted in a significant acceleration (by $21.2(8.2) \%$ ) of gastric emptying while feeding with a low protein diet was followed by a significant delay (by 24.0 (6.2)\%) of emptying rate (fig 2). When rats on high or low protein diets were put on a medium protein (regular) diet for just one week, gastric emptying reverted back to normal (no significant difference was found between emptying rate of each of these two groups and that of control animals) and no significant difference was found between the two groups (high versus low

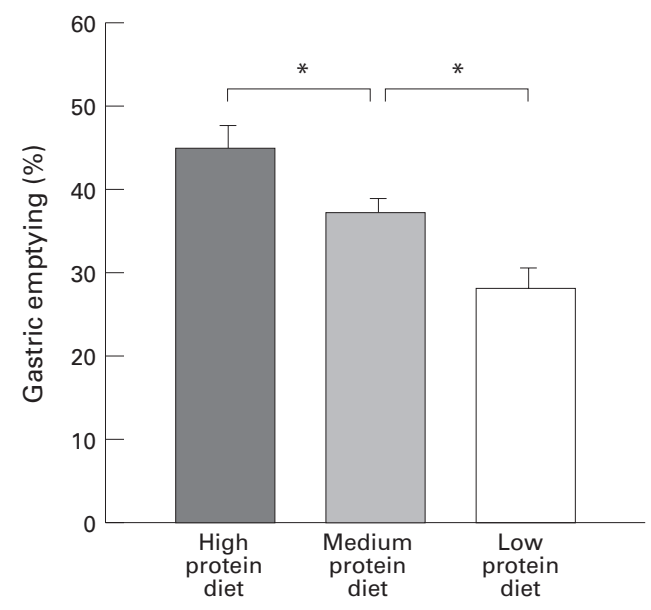

Figure 2: Gastric emptying of a peptone meal (over 40 minutes) in rats fed for 21 days with a high, medium, or low protein diet. Each column represents the mean of the values obtained from six to eight animals. Vertical bars are standard errors. ${ }^{\star} p<0.05$. 


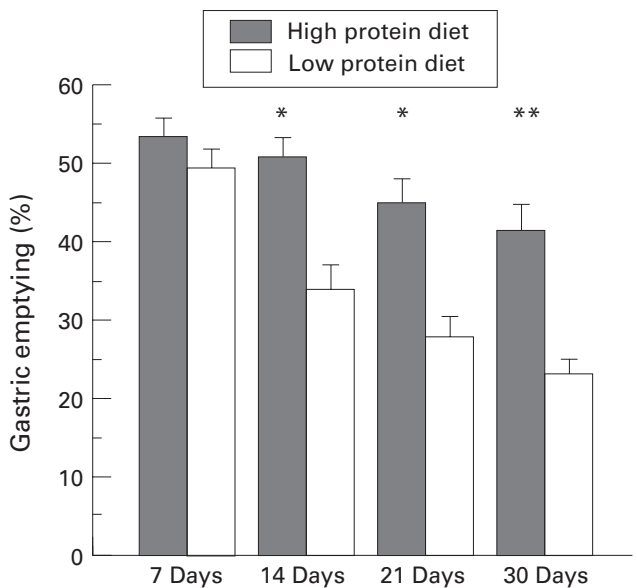

Figure 3: Gastric emptying of a peptone meal (over 40 minutes) in rats fed with a high or low protein diet for 7 , 14,21 , or 30 days. Each column represents the mean of the values obtained from six to eight animals. Vertical bars are standard errors. ${ }^{\star} p<0.01$ versus low protein diet, ${ }_{\star \star} p<0.001$ versus low protein diet.

protein diet: 44.9 (4.0)\% versus 43.5 (3.3)\%, $\mathrm{p}>0.05)$.

When the time course of the effect of dietary adaptation on gastric emptying was studied, it appeared evident that at least two weeks are required for dietary protein to be effective (fig 3 ). Indeed, only one week of feeding with diets of differing protein content was not sufficient to achieve a statistically significant difference between the two groups (fig 3). As expected, the higher the body weight (and therefore the age) of the animals, the slower the emptying rate. ${ }^{25}$ The inverse correlation between age and gastric emptying was significant in rats on both high and low protein diets.

The regulatory effect of dietary protein on gastric emptying proved to be dependent on meal composition. Indeed, only the emptying rate of a protein containing meal ( $40 \%$ peptone meal) was modified by previous dietary intake. On the contrary, no significant changes were observed with glucose and methylcellulose meals, whose emptying rates were similar in rats receiving a high protein or low protein diet (fig 4).

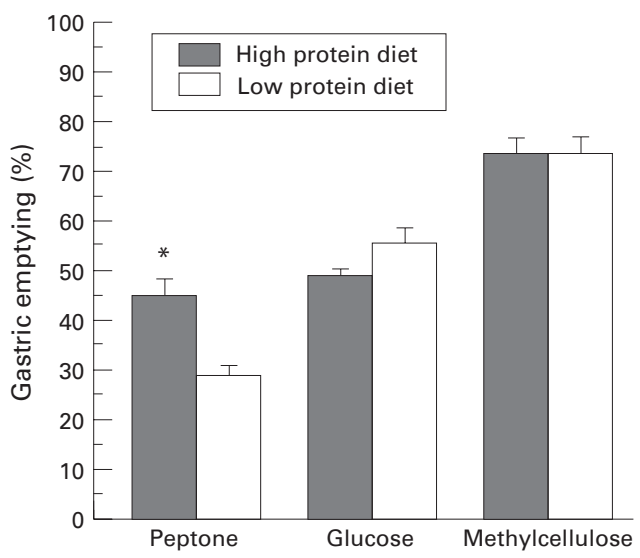

Figure 4: Gastric emptying of a peptone (over 40 minutes), glucose (over 20 minutes), or methylcellulose (over 15 minutes) meal in rats fed for 21 days with a high or low protein diet. Each column represents the mean of the values obtained from six to eight animals. Vertical bars are standard errors. ${ }^{\star} p<0.01$ versus low protein diet value.

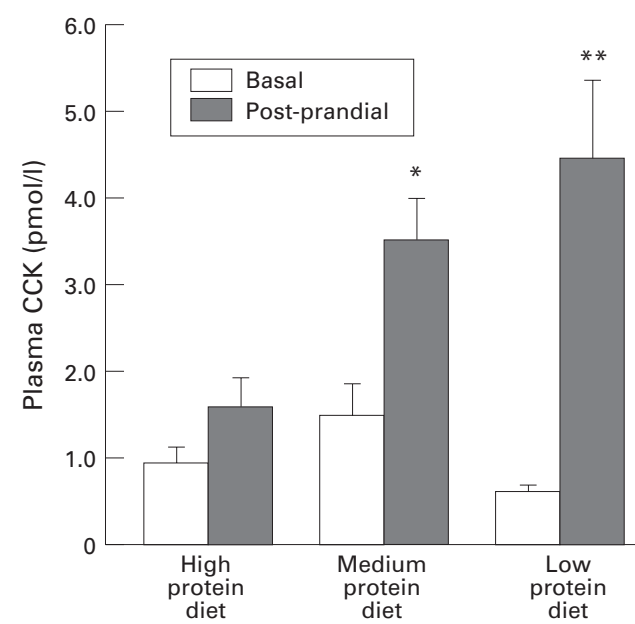

Figure 5: Basal and postprandial plasma CCK levels in rats fed for 21 days with a high, medium, or low protein diet. Peptone induced CCK release was measured eight minutes after the test meal. Each column represents the mean of the values obtained from six to nine animals. Vertical bars are standard errors. ${ }^{\star} p<0.05$ versus basal value, ${ }^{\star \star} p<0.01$ versus basal value.

EFFECT OF DIFFERENT TYPES OF PROTEIN INTAKE ON CCK RELEASE

Basal plasma CCK levels in control rats receiving a medium protein (regular) diet were 1.48 (0.37) $\mathrm{pmol} / \mathrm{l}$ and were not significantly different from those found in the plasma of animals fed with a high or low protein diet (fig 5). As expected, a peptone meal strongly and significantly increased plasma CCK levels in control rats. This also occurred in rats receiving a low protein diet but not in rats on a high protein diet (fig 5). As a consequence, postprandial plasma levels of CCK in rats fed with medium or low protein diets were significantly higher than those found in rats receiving a high protein diet.

EFFECT OF DIFFERENT TYPES OF PROTEIN INTAKE ON CCK mRNA

The postprandial mRNA levels (expressed as CCK mRNA to PGK mRNA ratio) in the duodenal mucosa were 89.16 (2.95)\% after adaptation to a high protein diet and 77.72 (5.36)\% after adaptation to a low protein diet, respectively $(\mathrm{p}=0.09)$.

EFFECT OF DIFFERENT TYPES OF PROTEIN INTAKE ON CCK INDUCED DELAY IN GASTRIC EMPTYING As previously reported, ${ }^{26}$ CCK-8 significantly delayed gastric emptying of a non-caloric liquid meal (methylcellulose meal) and this effect proved to be dose dependent (fig 6). In rats on high and low protein diets, dose response curves to CCK-8 were virtually identical, suggesting no influence of dietary protein intake on the effect of exogenous CCK.

\section{Discussion}

Results of the present investigation show that gastric emptying of a liquid test meal containing protein is significantly faster after a 21 day period on a high protein diet; the emptying rate is significantly slower after the same period on a low protein diet. This gastric motor adaptation seems to be time dependent since at least 


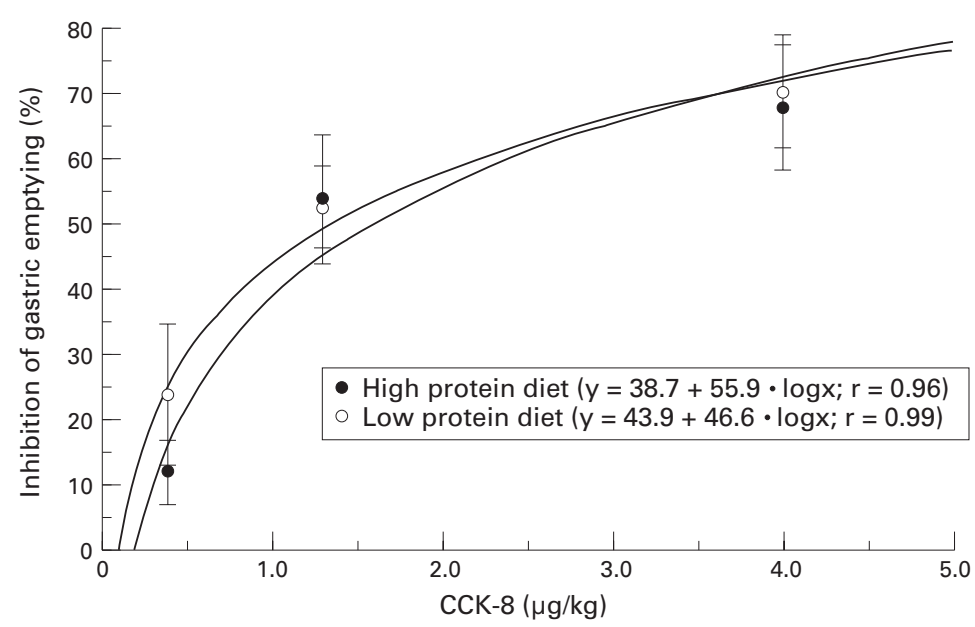

Figure 6: Dose response curves of the effect of CCK-8 on gastric emptying of a methylcellulose meal in rats fed for 21 days with a high or low protein diet. Each point represents the mean of the values obtained from six to eight animals. Vertical bars are standard errors. The graph displays a semilogarithmic plot of percentage inhibition versus dose. hormonal mediators. If this is the case, CCK might be the primary candidate since it has been shown to be released from "I" cells by the presence of proteins in the small intestine ${ }^{24} 28$ and to be capable of delaying gastric emptying. ${ }^{15}$ Thus, if a high protein diet accelerates gastric emptying by down regulating nutrient receptors in the small intestine, one would expect the postprandial plasma CCK response to be reduced. The converse should be true for the effect of low protein intake. In fact, the CCK response to a peptone meal was reduced after feeding with a high protein diet and increased after low protein diet. The diet induced changes in CCK release are consistent with diet induced modifications in emptying rate observed in our experimental conditions. In fact, after a peptone meal, the small intestinal mucosa of rats fed with low protein diet will release (within a few minutes) more CCK, which will, in turn, inhibit gastric emptying of the remaining meal, so that the observed emptying rate will be slower. On the contrary, when the duodenal mucosa has been desensitised by feeding with a high protein diet, less CCK will be released, so that one of the physiological brakes to emptying of gastric contents will be lessened and, consequently, final gastric emptying will seem faster. Although one time point was used for measurement of plasma CCK, these data suggest that endogenous CCK may have a role in the adaptive process. Recent data from our laboratory seem to confirm this hypothesis, since pretreatment of animals with devazepide, a selective CCK-A receptor antagonist, was able to prevent the adaptation of gastric emptying to diets with differing protein content. $^{27}$

The increase in postprandial CCK levels after feeding a low protein diet seems to reflect an increase in CCK release rather than CCK synthesis by "I" cells. Indeed, duodenal mucosal levels of CCK mRNA were not statistically affected by the different protein intake. These results are at variance from those reported by Liddle et $a l^{29}$ who found CCK release to be associated with changes in CCK mRNA levels. Differences in the experimental design - that is, different stimuli (protein meal versus soybean trypsin inhibitor) and different time intervals (six hours versus 12 or 24 hours) can be responsible for discrepancies in findings.

A different mechanism to explain the adaptation of gastric emptying to different types of protein intake could be a modification of gastric sensitivity to CCK. Obese rats, for instance, show a decreased sensitivity to $\mathrm{CCK}^{30}$ and it has been proposed that this may be a consequence of increased meal size. ${ }^{31}$ However, dose response curves to exogenous CCK-8 were the same in rats fed with high or low protein diets, suggesting that dietary regimens are unable to affect gastrointestinal sensitivity to exogenous CCK.

It is worth mentioning that CCK unrelated mechanisms also seem to be involved in the adaptive changes of gastric emptying or motility to diet since specific adaptation of gastric emptying ${ }^{34}$ or motility ${ }^{32}$ to glucose (which does not release $\mathrm{CCK}$ ) and rapid adaptive changes 
in the pyloric motor response to prolonged intraduodenal dextrose ${ }^{33}$ have been reported.

To summarise, gastric emptying of a protein containing meal can be modified by previous dietary protein intake. This effect, which is time dependent and meal specific, seems to be related to changes in endogenous CCK release which will affect emptying rate. While the exact mechanisms underlying this adaptive response need to be studied and clarified further, these results emphasise the importance of dietary history in the evaluation and interpretation of gastric emptying data.

Preliminary data from the present investigation have been presented to the American Gastroenterological Association (New Orleans) and appeared in abstract form (Gastroenterology 1994; 106: A566). This work was supported by a grant from the Institut National de la Santé et Recherche Médicale (INSERM, CRI No. 9508).

1 Meyer JH. Motility of the stomach and gastrointestina tract. 2nd edn. New York: Raven Press, 1987: 613-30.

2 Cunningham KM, Daly J, Horowitz M, Read NW Gastrointestinal adaptation to diets of differing fat composition in human volunteers. Gut 1991; 32:483-6.

3 Cunningham KM, Horowitz M, Read NW. The effect of short-term dietary supplementation with glucose on gastric emptying in humans. Br f Nutr 1991; 65: 15-9.

4 Horowitz M, Cunningham KM, Wishart JM, Jones KL, Read NW. The effect of short-term dietary supplementation with glucose on gastric emptying of glucose and fruction with glucose on gastric emptying of glucose and fruc-
tose and oral glucose tolerance in normal subjects. Diabetotose and oral glucose

5 Corvilain B, Abramowicz M, Fery F, Schoutens A, Verlinden M, Balasse E, Horowitz M. Effect of short-term starvation on gastric emptying in humans: relationship to oral glucose tolerance. Am F Physiol 1995; 269: G512-7.

6 Desai AJ, Moyer LL, Deveney CW, Sankaran H. Malnutrition significantly prolongs the delay in gastric emptying in rats. Nutr Res 1993; 13: 715-22.

7 Robinson PH, Stephenson JS. Dietary restriction delays gastric emptying in rats. Appetite 1990; 14: 193-201.

8 Forster ER, Dockray GJ. The role of cholecystokinin in inhibition of gastric emptying by peptone in the rat. Exp Physiol 1992; 77: 693-700.

9 Gregory PC, McFayden M, Rayner DV. Control of gastric emptying in the pig: influence of cholecystokinin, somato-

10 Jansen JBMJ, Fried M, Hopman WPM, Lamers CBHW, Meyer JH. Relation between gastric emptying of albuminMeyer JH. Relation between gastric emptying of albumin-
dextrose meals and cholecystokinin release in man. Dig Dis dextrose meals and cho

11 Konturek SJ, Kwiecien N, Obtulomicz W, Kopp B, Olesky J, Rovati L. Cholecystokinin in the inhibition of gastric secretion and gastric emptying in humans. Digestion 1990; 45: $1-8$.

12 Konturek JW, Thoer P, Maczka M, Stoll R, Domschke W, Konturek SJ. Role of cholecystokinin in the control of gastric emptying and secretory response to a fatty meal in normal subjects and duodenal ulcer patients. Scand $\mathcal{F}$ Gastroenterol 1994; 29: 583-90.

13 Moran TH, Ameglio PJ, Schwartz GJ, Peyton HJ, McHugh PR. Endogenous cholecystokinin in the control of gastric emptying of liquid nutrient loads in Rhesus monkeys. Am 7 Physiol 1993; 265: G371-5.

14 Moran TH, Kornbluh R, Moore K, Schwartz GJ. Cholecystokinin inhibits gastric emtying and contracts the pyloric sphincter in rats by interacting with low affinity receptor sites. Digestion 1994; 52: 165-72.

15 Scarpignato C, Varga G, Corradi C. Effect of CCK and its antagonists on gastric emptying. F Physiol (Paris) 1993; 87: 291-300.

16 Berthelemy P, Bouisson M, Vellas B, Moreau J, Vaysse N, Albarede JL, Fbat A. Postprandial cholecystokinin secre-
tion in elderly with protein-energy undernutrition. $\mathcal{f} \mathrm{Am}$ tion in elderly with protein-
Geriatr Soc 1992; 40: 365-9.

17 Wisen O, Bjorvell H, Cantor P, Johansson C, Theodorsson E. Plasma levels of regulatory peptides in obesity following modified sham feeding (MSF) and a liquid test meal. Regul Pept 1992; 39: 43-54.

18 Harty RF, Pearson PH, Solomon TE, McGuigan JE. Cholecystokinin, vasoactive intestinal peptide and peptide histidine methionine responses to feeding in anorexia nervosa. Regul Pept 1991; 36: 141-50.

19 Green GM, Levan VH, Liddle RA. Plasma cholecystokinin and pancreatic growth during adaptation to dietary protein. Am f Physiol 1986; 251: G70-4.

20 Kanayama S, Liddle RA. Influence of food deprivation on intestinal cholecystokinin and somatostatin. Gastroenterology 1991; 100: 909-15.

21 Scarpignato C, Capovilla T, Bertaccini G. Action of caerulein on gastric emptying in the conscious rat. Arch Int Pharmacodyn Ther 1980; 246: 286-94.

22 Scarpignato C. Mesure de la vidange gastrique des liquides chez le rat. $\mathcal{F}$ Pharmacol (Paris) 1983; 14: 261-8.

23 Liddle RA, Goldfine ID, Williams JA. Bioassay of plasma cholecystokinin in rats: effects of food, trypsin inhibitor and alcohol. Gastroenterology 1984; 87: 542-9.

24 Liddle RA, Green GM, Conrad CK, Williams JA. Proteins but not amino acids, carbohydrates, or fats stimulate cholecystokinin secretion in the rat. Am f Physiol 1986; 251: 243-8.

25 Chomszynski P, Sacchi N. Single-step method of RNA isolation by acid guanidinium thiocyanate-phenol-chloroform extraction. Anal Biochem 1987; 162: 156-9.

26 Scarpignato C, Kisfalvi I, D'Amato M, Varga G. Effect of dexloxiglumide and spiroglumide, two new CCK-receptor antagonists, on gastric emptying and secretion in the rat: evaluation of their receptor selectivity in vivo. Aliment Pharmacol Ther 1996; 10: 411-9.

27 Shi G, Bruley des Varannes S, Cherbut C, Rozé C, Galmiche JP. Diet-induced changes of gastric emptying in rats: involvement of endogenous CCK [abstract]. Gastroenterology 1997; 112: A654.

28 Liddle RA. Regulation of cholecystokinin synthesis and secretion in rat intestine. 7 Nutr 1994; 124: 1308-14.

29 Liddle RA, Carter JD, McDonald AR. Dietary regulation of rat intestinal CCK gene expression. $\mathcal{F}$ Clin Invest 1988; 81: 2015-9.

30 McLauglin CL, Baille CA. Decreased sensitivity of Zucker obese rat to the putative satiety agent cholecystokinin. Physiol Behav 1980; 25: 543-8.

31 Baille CA, McLauglin CL, Della-Fera MA. Role of cholecystokinin and opioid peptides in control of food intake. Physiol Rev 1986; 66: 172-234.

32 Raybould HE, Zittel TT. Inhibition of gastric motility induced by intestinal glucose in awake rats: role of $\mathrm{Na}^{+}$-glucose co-transporter. Neurogastroenterol Motil 1995; 7: $9-14$

33 Edelbroek M, Horowitz M, Fraser R, Wishart J, Morris H, Dent J, Akkermans L. Adaptive changes in the pyloric motor response to intraduodenal dextrose in normal subjects. Gastroenterology 1992; 103: 1754-61. 